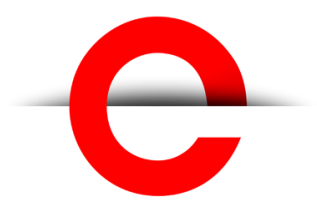

U T S

e PRES S
International Journal

of Rural Law and

Policy

No. 12018

\title{
Local Voices on forced mergers in small rural Australian communities:The case of the Guyra Shire Council
}

\author{
Andrea Wallace $^{1 *}$, Brian Dollery ${ }^{2}$ \\ ${ }^{1}$ Centre for Local Government, UNE School of Business, University of New England, \\ Armidale NSW 2351, Australia. awalla22amyune.edu.au \\ 2 UNE Law School, University of New England, Armidale NSW 2351, Australia. \\ bdolleryaune.edu.au
}

*Corresponding author: Andrea Wallace, University of New England, Armidale NSW 2351, Australia. awalla22amyune.edu.au

DOI: https://doi.org/10.5130/ijrlp.1.2018.6052

Article History: Received 28/04/2018; Revised 12/09/2018; Accepted 12/10/2018; Published $12 / 11 / 2018$

\begin{abstract}
When an Australian state or territory government launches a program of forced municipal mergers, it typically attracts much less attention in metropolitan areas compared with regional, rural and remote locations where the local council is often 'government of last resort'. In these areas, the socio-economic effects of compulsory council consolidation can be severe. Tis paper explores the perceived impact of the forced amalgamation of Guyra Shire Council with the much larger neighbouring Armidale Dumaresq Council under the recent New South Wales (NSW) Government's Fit for the Future structural reform program as anticipated by Guyra residents who participated in a focus group.
\end{abstract}

\section{Keywords}

\section{Amalgamation; Fit for the Future; Guyra; rural Australia}

DECLARATION OF CONFLICTING INTEREST The author(s) declared no potential conflicts of interest with respect to the research, authorship, and/or publication of this article. FUNDING This work was supported through funding from the Australian Government Department of Agriculture and Water Resources as part of its Rural R\&D for-Profit program and was co-funded by all 15 Rural and Development Corporations (RDCs). The 'Accelerating Precision Agriculture to Decision Agriculture' project was led by the Cotton Research and Development Corporation (CRDC). The views expressed herein do not necessarily represent the views of the CRDC, the RDCs or the other research partners. 


\section{Introduction}

In metropolitan Australia, council boundaries are often simply demarcated by city streets and residents are frequently unaware of the council area in which they live. In regional, rural and remote parts of the country, however, local government typically represents 'government of last resort' to its residents. Life in country Australia is also different in other ways from its suburban counterparts: incomes are frequently lower; health and educational outcomes poorer; employment opportunities scant; and the population is older. ${ }^{1}$ Notwithstanding, social capital, community connectivity, a sense of belonging and local 'place and space' are often more valued. ${ }^{2}$ These characteristics are sometimes ascribed to local government; ${ }^{3}$ the local council is much more than simply 'roads, rates and rubbish', because it is often the largest local employer, the major source of significant local expenditure and, frequently, the only body able to advance the interests of the local community. In addition to being the engine of the local economy, local government is the forum for grass roots democracy; ${ }^{4}$ it coordinates local social capital in the form of volunteers and provides amenities for the community which would otherwise be unavailable. In essence, the hardships of life in the bush are often softened by local councils.

The special characteristics of rural local government have come at a cost, whether it be the maintenance of vital road networks, the provision of emergency services or the commitment by a bush council to provide basic services. Given the demands placed upon them, many non-metropolitan councils have experienced financial problems, which have obliged state government policymakers to consider various kinds of policy intervention, including forced amalgamation.

Structural reform through council consolidations has reshaped local government in both Australia ${ }^{5}$ and abroad. For instance, New Zealand, ${ }^{6}$ the US, ${ }^{7}$ Canada $^{8}$ and Switzerland ${ }^{9}$ have all experienced forced amalgamation, predicated, in large part, on the assumption that larger administrative units servicing more people will be more efficient as well as financially sustainable. In common with numerous local government systems in other developed countries, Australian local government policy makers in all state and territories, except Western Australia, have employed municipal mergers of varying degrees of intensity. ${ }^{10}$

In 2014, the New South Wales (NSW) Government introduced a new wave of local government reforms following its earlier round of forced amalgamations in 2004. Its Fit for the Future policy package was instigated in September 2014. Each council in NSW was obliged to undergo evaluation to determine if it was 'fit for the future'. Despite the lack of local government homogeneity across NSW, each council was subject to the same evaluation criteria. The Guyra Shire Council (GSC) was one among many councils which was found 'unfit'. As a consequence, and despite vociferous opposition by local residents, the GSC was forcibly amalgamated with its neighbour, the Armidale Dumaresq Council (ADC), on 12 May 2016.

While a substantial literature has examined the economic and financial consequences of forced mergers in Australian local government, ${ }^{11}$ almost no scholarly work has explored the attitudes of the residents of rural councils which have been compulsorily consolidated. In order to address this gap in the literature, the present paper examines the expectations of GSC residents - as articulated by a focus group comprised of residents of the former GSC local government area - on the likely impact of the forced amalgamation.

The next section of this paper provides an overview of the Fit for the Future policy process and is followed by a synoptic account of the existing scholarly literature on municipal mergers. The paper then considers

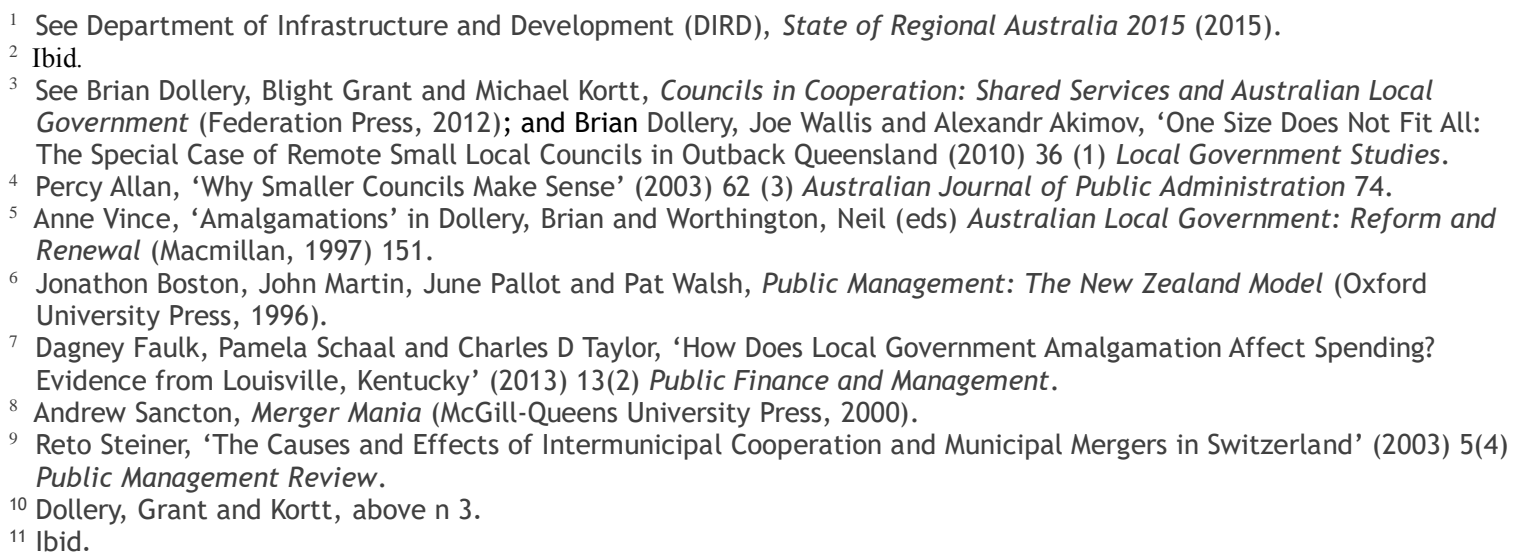


the GSC in the context of the Fit for the Future policy process. The ex ante expectations of post-merger life through the lived experience of Guyra residents are examined in Section 5 . The paper ends with some brief conclusions in Section 6.

\section{Fit for the Future evolution and execution}

The Fit for the Future policy framework was formulated by an 'Independent Panel' in conjunction with forprofit consultancy firms, notably KPMG and, almost from the outset, was based largely on the claim that larger local government entities would (a) prove more financially sustainable and (b) have greater 'scale and capacity'. In addition, the 'shifting sands' of the assessment criteria upon which councils were evaluated in Fit for the Future followed an incoherent and disconnected process with little accountability. ${ }^{12}$ Given the importance of the policy process and lack of strategic consistency, it is essential to clarify the chronological construction of the Fit for the Future policy. Appendix A summarises the policy process.

The Fit for the Future policy was initiated after the election of the National/Liberal Government in 2011, despite the fact that it had campaigned on a 'no amalgamation' platform. Don Page, then Minister of Local Government, claimed NSW local government required urgent remedial attention. ${ }^{13}$ A conference of all NSW local authorities was held in Dubbo in August 2011, where he announced the establishment of an Independent Local Government Review Panel (ILGRP), consisting of Graham Sansom, Jude Munro and Glenn Inglis, which was tasked with reviewing reform options for local government. The ILGRP released its first substantial report, noting that there was a 'need for fresh thinking and new approaches in NSW local government'. ${ }^{14}$ The ILGRP promised that a 'one size fits all' approach to reform would not occur, ${ }^{15}$ and that if mergers were to be considered then individualised proposals would be formulated.

The ILGRP acknowledged that empirical evidence relating to the outcomes of the 2004 NSW amalgamations was required. It engaged Jeff Tate Consulting to report on the 2004 amalgamations. However, the Tate Report ${ }^{16}$ was restricted by the ILRGP to assessing the outcomes of five councils. In the event, research by Jeff Tate Consulting was based on discussions with senior management staff of these councils, including many hired after amalgamation. Two of the five councils in question were subsequently adjudged unfit under Fit for the Future! ${ }^{17}$ Table 1 summarises the evaluations received by these councils.

Table 1: TCorp (2013) and IPART (2015) rating of five councils analysed in Tate (2013) report

\begin{tabular}{lcll}
\hline \multicolumn{1}{c}{ Council } & TCorp- FSR & TCorp-outlook & IPART rating \\
\hline Clarence Valley Council & Weak & Negative & Not Fit \\
Glen Innes Severn & Moderate & Neutral & Fit \\
Palerang Council & Moderate & Negative & Not Fit \\
Great Hume Shire & Moderate & Negative & Fit \\
City of Albury & Moderate & Neutral & Fit \\
\hline
\end{tabular}

Source: Tate (2013); TCorp (2013); IPART (2015)

The ILGRP released an interim report and a final report, both of which recommended the compulsory merger of numerous NSW councils ${ }^{18}$ and the strengthening of the NSW Boundaries Commission. The case for mergers was largely based on the claim that 'NSW simply cannot sustain 152 councils'. ${ }^{19}$ These recommendations were formed upon an assessment of financial sustainability presented in a NSW Treasury Corporation (TCorp) report, ${ }^{20}$ which was considered by Drew and Dollery to be 'awash with error' and

\footnotetext{
12 Joseph Drew and Bligh Grant, 'Multiple Agents, Blame Games and Public Policy-Making: The Case of Local Government Reform in New South Wales' (2017) 52 (1) Australian Journal of Political Science 37.

${ }^{13}$ Don Page, 'New South Wales Local Government Reform 2011 to 2014' in Brian Dollery and lan Tiley (eds) Perspectives on Australian Local Government Reform (Federation Press, 2015) 172.

${ }^{14}$ Independent Local Government Review Panel (ILGRP), Better Stronger Local Government: The Case for Change (2012) 6.

15 Ibid 24

${ }^{16}$ Tate Consulting Pty Ltd, Assessing Processes and Outcomes of the 2004 Local Government Boundary Changes in NSW (McLaren Vale, South Australia, 2013).

${ }^{17}$ Ibid 23-24.

${ }^{18}$ See both ILGRP, Future Directions for NSW Local Government: Twenty Essential Steps (2013) and ILGRP, Revitalising Local Government (2013).

${ }^{19}$ ILGRP, Revitalising Local Government, above n 18, 72.

${ }^{20}$ NSW Treasury Corporation (TCorp), Financial Sustainability of the New South Wales Local Government Sector (2013).
} 
lacking coherence in its benchmarking methodology. ${ }^{21}$ Despite ILGRP's protestations that there would be no 'One Size Fits All' approach in the reform process, at no stage were the individual requirements of local communities considered by the expert panel, nor were any longstanding problems that NSW councils had faced due to legislative proscriptions considered. ${ }^{22}$

Fit for the Future was made public in January 2014 and implementation began in September 2014 after a cabinet reshuffle. ${ }^{23}$ Attractive financial incentives were offered to councils that merged voluntarily. ${ }^{24}$ As part of the policy process, each council had to prepare a submission stating its preference to either merge or 'standalone'. Twenty-five days before council submissions were due, the Independent Pricing and Regulatory Tribunal (IPART) formally released the criteria on which Fit for the Future evaluations would be based, effectively truncating the amount of time available for councils to prepare formal proposals. The shifting sands of assessment were now based upon 'adequate scale and capacity', but no definition was provided. On 18 December 2015, the NSW Government announced its decision on council consolidations.

Delegates were appointed by the NSW Boundaries Commission in 2016 to oversee community consultation in local government areas where an amalgamation was recommended. Forced mergers were pushed through on 12 May 2016, which initiated the dissolution of 49 councils and the creation of 19 newly merged institutions. However, several Sydney councils, including Ku-ring-gai and Woollahra, initiated legal proceedings against the NSW Government. The NSW Court of Appeal ruled in favour of Ku-ring-gai, because the merger process had not followed procedural fairness. Legal proceedings were halted by the NSW Government on 27 July 2017 without explanation, and the outstanding mergers abandoned. The Fit for the Future process thereby ended under a Berejiklian Government keen to rid itself of the political unpopularity of the forced merger program.

\section{KPMG report}

Engaged by the NSW Government, KPMG undertook financial modelling on the expected financial advantages that would accrue if the potential merger program was implemented. Its report ${ }^{25}$ was released for cabinet circulation in late 2015 and underwrote the selection of councils targeted for amalgamation. The NSW Government repeatedly refused access to the document when requested by affected councils, instead offering a summary replete with normative rhetoric. ${ }^{26}$ However, a synopsis of the methodology employed in the original report ${ }^{27}$ was circulated.

The KPMG methodology attracted criticism. For instance, Dollery and Drew ${ }^{28}$ noted that KPMG had used incorrect rates for councillor remuneration and the wrong award for council staff redundancies. It also used different calculation rates to those employed in previous financial modelling reports which KPMG had prepared for NSW local government, neglected the costs of service harmonisation entirely ${ }^{29}$ and failed to categorise councils correctly by type.

\section{Empirical evidence on municipal mergers}

The ILGRP argued that its recommendations for the amalgamation of a number of councils were evidencebased. ${ }^{30}$ Furthermore, the ILGRP stated that evidence was highly suggestive that many merged council functions, such as back-office administration, would generate scale economies and regional economic

\footnotetext{
${ }^{21}$ Joseph Drew and Brian Dollery, 'Estimating the Impact of the Proposed Greater Sydney Metropolitan Amalgamations on Municipal Financial Sustainability’ (2014) 34 (4) Public Money and Management 281; and Joseph Drew and Brian Dollery, 'Summary Execution: The Impact of Alternative Summarisation Strategies on Local Government' (2016) 40 (4) Public Administration Quarterly 814.

${ }^{22}$ Peter Abelson and Roselyne Joyeux, 'New Development: Smoke and Mirrors - Fallacies in the New South Wales Government's Views on Local Government Financial Capacity' (2015) 35 (4) Public Money and Management 315.

${ }^{23}$ Office of Local Government, A Roadmap for Smarter, Stronger Councils (Office of Local Government, 2014).

${ }^{24}$ See Joseph Drew and Brian Dollery, Brian, 'Less Haste, More Speed: The Fit for the Future Reform Program in New South Wales Local Government' (2015) 75 (1) Australian Journal of Public Administration 7.

${ }^{25}$ KPMG, Local Government Reforms: Merger Impact and Analysis (2015).

${ }^{26}$ New South Wales Government, Local Government Reform: Merger Impacts and Analysis (2015).

${ }^{27}$ KPMG, Outline of Financial Modelling Assumptions for Local Government Merger Proposals (KPMG, 2016).

${ }^{28}$ Brian Dollery and Joseph Drew, 'Hired Guns: Local Government Mergers in New South Wales and the KPMG Modelling Report' (2017) 27 (82) Australian Accounting Review 263.

29 Interestingly, KPMG also neglected the cost of service harmonisation when collating a report concerning the Toronto amalgamation in 1996, see Sancton, above n 8, 126.

${ }^{30}$ ILGRP, Revitalising Local Government, above n 18, 7, 10
} 
development would be stimulated. ${ }^{31}$ However, even the flawed Tate Report ${ }^{32}$ showed some merged councils did not save money, even after nearly a decade post-merger.

The Fit for the Future policy process generated a substantial body of empirical evidence in the scholarly literature. This literature is summarised in Table 2, with this paper contributing further the range of studies by examining the attitudes and expectations of GSC residents; to this end, it invokes the views of a focus group of Guyra residents on the forced merger of the GSC.

Table 2: Australian literature of Fit for the Future

\begin{tabular}{|c|c|}
\hline Citation & Data \\
\hline \multirow[t]{5}{*}{$\begin{array}{l}\text { Peter Abelson, 'The Optimal Size of Local } \\
\text { Government, with Special Reference to } \\
\text { New South Wales' (2016) } 23 \text { (1) Agenda } 31 \text {. }\end{array}$} & $\begin{array}{l}\text { Discussion of criteria to assess } \\
\text { optimum size for local } \\
\text { government: }\end{array}$ \\
\hline & $\begin{array}{l}\text { 1. capacity to work with state } \\
\text { government }\end{array}$ \\
\hline & $\begin{array}{l}\text { 2. financial capacity/economic } \\
\text { efficiency }\end{array}$ \\
\hline & $\begin{array}{l}\text { 3. effective provision of local } \\
\text { services }\end{array}$ \\
\hline & $\begin{array}{l}\text { 4. beneficial local democracy and } \\
\text { social capital. }\end{array}$ \\
\hline
\end{tabular}

Peter Abelson and Roselyne Joyeaux, 'New Development: Smoke and Mirrors--Fallacies in the New South Wales Government's Views on Local Government Financial Capacity' (2015) 35 (4) Public Money and Management 315.

Brian Bell, Brian Dollery and Joseph Drew, 'Learning from Experience in NSW?' (2016) 35 Economic Papers 1.

\section{Explanation of differences in} expenditure per capita by difference in income and services from evidence of 27 metropolitan Sydney councils.

\section{Examination of ILGRP's empirical} evidence of the impact of 2004 mergers by using a system-wide analysis between merged and unmerged councils over the period 2004/2014.
Merged councils did not perform any better than unmerged councils.
1. Increased capacity for councils to work with state government an invalid reason for mergers.

2. Strong empirical evidence that larger administrative units do not produce cost savings.

3. Local service preferences are better served by smaller councils.

Larger councils will not improve financial capacity in NSW.
Analyses the association between population size and improved financial sustainability in the Greater Sydney region.
Proposed amalgamations will not improve financial sustainability.
Impact of Metropolitan Amalgamations in

Sydney on Municipal Financial

Sustainability' (2014) 34 (4) Public Money

Management 281.
Analyses the KPMG financial modelling methodology report.
KPMG report awash with calculation errors and erroneous conjecture.
Guns: Local Government Mergers in New South Wales and the KPMG Modelling

Report' (2017) 27 (82) Australian Accounting Review 263.

Joseph Drew, Bligh Grant, and Nicole Campbell, 'Progressive and Reactionary Rhetoric in the Municipal Reform Debate in New South Wales' (2016) 512 Australian Journal of Political Science 323.

Joseph Drew and Bligh Grant, 'Multiple Agents, Blame Games and Public Policymaking: The Case of Local Government Reform in New South Wales' (2017) 52 (1) Australian Journal of Political Science 37.

Joseph Drew, Michael Kortt and Brian Dollery, 'No Aladdin's Cave in New South Wales? Local Government Amalgamation, Scale Economies, and Data Envelopment Analysis Specification' (2015) 49

(10)Administration and Society 49, 1450.
Theoretical analysis of the political discourse surrounding empirical evidence employed during the Fit for the Future policy reform process.

Employs a blame-avoidance hypothesis with which to unravel the Fit for the Future policy process.

Examines municipalities scheduled for merger for economies of scale by DEA.
Empirical evidence used to defend an argument may often be too complex, and alternate ways should be used to articulate political and economic discourse.

NSW Government used a variety of independent experts and forprofit companies to deflect criticism during the evolution and execution of an emotive, unpopular public policy process.

Amalgamation is not the ideal method to achieve economies of scale in NSW local government.

\footnotetext{
${ }^{31}$ Ibid 73.

32 Tate Consulting, above n 16, 23-24.
} 


\begin{tabular}{|c|c|c|}
\hline Citation & Data & Principal findings \\
\hline $\begin{array}{l}\text { Glenn Fahey, Joseph Drew and Brian } \\
\text { Dollery, 'Merger Myths: A Functional } \\
\text { Analysis of Scale Economies in New South } \\
\text { Wales Local Government' (2016) 16 (4) } \\
\text { Public Finance and Management } 362 .\end{array}$ & $\begin{array}{l}\text { Expenditure analysis for NSW local } \\
\text { government using } 2014 \text { data to } \\
\text { test ILGRP's hypothesis that } \\
\text { amalgamation will create } \\
\text { economies of scale. }\end{array}$ & $\begin{array}{l}\text { Given that council consolidation is } \\
\text { as ineffective as it is disruptive, } \\
\text { and due to the heterogeneous } \\
\text { nature of council services and } \\
\text { functions, economies of scale are } \\
\text { unlikely to be achieved through } \\
\text { amalgamation. }\end{array}$ \\
\hline $\begin{array}{l}\text { Bligh Grant, Roberta Ryan and Alex Lawrie, } \\
\text { 'Dirty Hands and Commissions of Inquiry: } \\
\text { An Examination of the ILGRP in NSW, } \\
\text { Australia' (2015) } 13 \text { Research in Ethical } \\
\text { Issues in Organizations } 19 .\end{array}$ & $\begin{array}{l}\text { Philosophical examination of the } \\
\text { ethics of the commission of } \\
\text { inquiry with discussion of ILGRP } \\
\text { inquiry as evidence. }\end{array}$ & $\begin{array}{l}\text { The confusion and role of } \\
\text { commissions of inquiry is partly } \\
\text { responsible for allegations of } \\
\text { ethical incoherence. }\end{array}$ \\
\hline $\begin{array}{l}\text { Don Page, 'New South Wales Local } \\
\text { Government Reform } 2011 \text { to 2014' in } \\
\text { Perspectives on Australian Local } \\
\text { Government Reform in Brian Dollery and } \\
\text { lan Tiley (eds) (Federation Press, 2015) } \\
172 .\end{array}$ & $\begin{array}{l}\text { A brief outline of the genesis of } \\
\text { the Fit for the Future policy } \\
\text { process from the perspective of } \\
\text { then Minister of Local } \\
\text { Government, Don Page. }\end{array}$ & $\begin{array}{l}\text { The relationship between local } \\
\text { and state government was } \\
\text { detrimental to the economic } \\
\text { development of NSW, thus } \\
\text { remedial reform was necessary. }\end{array}$ \\
\hline $\begin{array}{l}\text { Roberta Ryan, Catherine Hastings, Bligh } \\
\text { Grant, Alex Lawrie, Éidín Ní Shé and Liana } \\
\text { Wortley, 'The Australian Experience of } \\
\text { Municipal Amalgamation: Asking the } \\
\text { Citizenry and Exploring the Implications' } \\
\text { (2015) } 75 \text { (3) Australian Journal of Public } \\
\text { Administration } 37 .\end{array}$ & $\begin{array}{l}\text { Survey of } 2006 \text { Australians to elicit } \\
\text { opinions of the implications of } \\
\text { council consolidation. }\end{array}$ & $\begin{array}{l}\text { Survey sample not large enough to } \\
\text { consider the implications of } \\
\text { municipal merger for all of } \\
\text { Australia. }\end{array}$ \\
\hline
\end{tabular}

\section{Guyra Shire Council and Fit for the Future}

Located $45.5 \mathrm{~km}$ north of Armidale in the Northern NSW Tablelands, GSC covers 4390 square kilometres, with a population of $4397^{33}$ and a road network of $970 \mathrm{~km}$, which included several small villages. Its Gross Regional Product for the period 2011-2012 was $\$ 1570000000 .{ }^{34}$ The GSC was established in 1906. Like many small rural councils in Australia, the GSC has many positive characteristics but, given its large road network and low population, it faced financial problems. A shared services arrangement that provided council IT and back-office support was already in place with the neighbouring ADC prior to the merger (which was overlooked in the KPMG assessment of the GSC).

As shown in Table 3, the evolution of Guyra's forced amalgamation began with the state-wide TCorp ${ }^{35}$ report, which showed that while Guyra's financial sustainability rating was 'moderate' at present, its future outlook was 'negative'. Financial sustainability in local government was defined by TCorp ${ }^{36}$ as 'when it [the council] is able to generate sufficient funds to provide the levels of service and infrastructure agreed with its community'. Population size for all rural councils was considered problematic by TCorp because low population densities would not be able to generate enough income for councils to meet their underlying expenditures. This was the impetus for the ILGRP's initial merger recommendation for Guyra: a proposed amalgamation of Walcha Shire, Uralla Shire, Armidale Dumaresq and Guyra Shire.

Merger plans for Guyra were revised in October 2013, with the ILGRP instead recommending the merger of only Armidale and Guyra. A period of community consultation began in November 2014, where the GSC elicited views from its residents. In June 2015, the GSC submitted a Rural Council Proposal to IPART for evaluation, outlining its position and community views regarding amalgamation.

GSC's ${ }^{37}$ proposal charted how it would fortify its financial and strategic position while strengthening its financial situation. It also stated that the maintenance of rural roads was expensive yet vital to the health, safety and economies of the region's residents, and that community services, such as aged care, childcare and home support, were also provided by the GSC because these services would otherwise be unavailable to Guyra residents. Residents agreed to a rate rise of 30 per cent in order to increase revenue and retain the

\footnotetext{
${ }^{33}$ Australian Bureau of Statistics (ABS), Local Government Profile Guyra (2011).

${ }^{34}$ NSW Parliamentary Research Service, The New England North-West Region: An Economic Profile (New South Wales Government, 2014) 4

${ }^{35}$ TCorp, Guyra Shire Council--Financial Assessment and Benchmarking Report (NSW Treasury Corporation, 2013)

${ }^{36}$ TCorp, Financial Sustainability of the New South Wales Local Government Sector, 14

${ }^{37}$ Guyra Shire Council, Rural Council Proposal (Guyra Shire Council, 2015)
} 
council's 62 full-time council employees, the impact of the loss of which was delineated in the economic impact assessment compiled by Regional Development Australia. ${ }^{38}$ Community attitudes were noted in GSC's proposal to IPART, since 85 per cent of Guyra residents did not wish to amalgamate with the AD largely because of fears that the ADC would dominate the subsequent merged entity due $t$ its comparatively larger size and different governance values. ${ }^{39}$

Table 3: GSC and Fit for the Future procedural timeline

\begin{tabular}{ll}
\hline Date & Event \\
\hline March 2013 & TCorp's (2013) analysis of GSC indicated improvement over recent years. \\
April 2013 & TCorp's (2013a) Financial Sustainability of the NSW Local Government Sector report released. GSC \\
& FSR: Moderate, Outlook: Negative.
\end{tabular}

April $2013 \quad$ ILGRP recommends the merger of the Guyra Shire, Walcha Shire, Uralla Shire and Armidale Dumaresq Councils into a single entity.

October $2013 \quad$ ILGRP recommends the merger of GSC with ADC.

September 2014 The Fit for the Future policy process is implemented by NSW Government.

November 2014 GSC launches a community engagement strategy, as per ILGRP's recommendations, across the entire shire to seek constituents' opinion regarding a possible merger.

June 2015

Regional Development Australia, Northern Inland NSW releases The Economic Impacts of Local Government Amalgamations, which shows the potential loss of local economic activity resulting from a forced council merger and associated centralised employment.

30 June 2015 GSC submit its Rural Council Proposal to IPART for evaluation. The proposal indicated that GSC residents did not wish to merge and would prefer to raise their rates by $30 \%$.

October $2015 \quad$ IPART evaluation of Guyra released and found 'unfit'. GSC was able to respond to IPART by November.

18 December 2015 Merger of GSC with ADC announced.

January 2016

NSW Government releases ADC and GSC Merger Proposal.

11 February 2016

Greg Wright is appointed Delegate by the NSW Boundaries Commission to oversee community consultation and merger process as per the Local Government Act 1993.

26 April 2016 Boundary Commission report to NSW Government is released, demonstrating due process was followed by the Delegate.

12 May 2016 Dissolution of GSC. Armidale Regional Council is created.

Sources: TCorp (2013); TCorp (2013a); GSC (2015); IPART (2015), RDA (2015)

By October 2015, GSC was found unfit as per IPART's five-part evaluation criteria. GSC did not satisfy 'scale and capacity', 'financial criteria', 'sustainability' or 'efficiency', but met the 'infrastructure and service management' criteria. The ADC was also found by IPART to be unfit. Notwithstanding the ILGRP' $\mathrm{s}^{40}$ undertaking not to amalgamate two or more weak councils, the merger of GSC and ADC was announced on 18 December 2015.

The NSW Government considered the two communities as compatible 'communities of interest'. The differences and similarities between the two previous local government areas are shown in Table 4.

Table 4: Armidale Dumaresq and Guyra Shire Local Government Areas 2006-2011

\begin{tabular}{lcccc}
\hline Measure & Guyra 2006 & Guyra 2011 & $\begin{array}{l}\text { Armidale } \\
\text { Dumaresq 2006 }\end{array}$ & $\begin{array}{l}\text { Armidale } \\
\text { Dumaresq 2011 }\end{array}$ \\
\hline Population & 4229 & 4397 & 23368 & 24105 \\
\hline Median age & 39 & 41 & 34 & 35 \\
\hline Unemployment & $7.7 \%$ & $6.5 \%$ & $8.3 \%$ & $7.4 \%$ \\
\hline $\begin{array}{l}\text { Main industry of } \\
\text { employment }\end{array}$ & $\begin{array}{l}28.3 \% \text { sheep, beef, } \\
\text { cattle farming }\end{array}$ & $\begin{array}{l}25.6 \% \text { sheep, beef, } \\
\text { cattle farming }\end{array}$ & $\begin{array}{l}12.1 \% \text { tertiary } \\
\text { education }\end{array}$ & $\begin{array}{l}11.3 \% \text { tertiary } \\
\text { education }\end{array}$ \\
\hline $\begin{array}{l}\text { Median household } \\
\text { weekly income }\end{array}$ & $\$ 704$ & $\$ 805$ & $\$ 855$ & $\$ 991$ \\
\hline
\end{tabular}

Source: ABS (2006; 2011)

Guyra is an older, less affluent population than the Armidale population and it is predominantly focused on agricultural production; whereas Armidale's population is younger and more affluent with primary,

\footnotetext{
${ }^{38}$ Regional Development Australia, Northern Inland (RDA), The Economic Impacts of Local Government Amalgamations (Issue Report no 9, 2015).

${ }^{39}$ Guyra Shire Council, above n 34, 46.

${ }^{40}$ ILGRP, above n 14, 23.
} 
secondary and higher education a major employer. Research commissioned as part of ILGRP's local government evaluation process also highlighted disparities between the two communities, such as lack of commuter work flows between the two communities, differing employment opportunities and varied demographics ${ }^{41}$. It did not find evidence of social or economic interdependence.

\section{Methodology}

This paper seeks to highlight the ex ante expectations of the effects of forced municipal mergers upon a small rural Australian community and to further elucidate the wider social and economic implications of structural reform policy in non-metropolitan Australia by considering the views of residents of the former GSC area. A focus group of informed adults residing in the former GSC local government area was considered the most practicable vehicle through which to garner the lived experience of rural communities through forced local government amalgamation. The use of a focus group, with its inherent rich forms of qualitative data through anecdotal evidence and justifications, enabled a marginalised group to vocalise its experiences of the Fit for the Future policy process. The method also opened new lines of enquiry into the effects of compulsory council consolidation in rural, remote and regional Australia as well as providing an alternate textural context. The approach differs from the normative quantitative approach favoured by empirical scholars regarding the on-going debate surrounding structural reform in Australian local government.

The focus group was held in September 2017 in Guyra and the discussion lasted about two hours. The group was self-organised and comprised eight, anonymous individuals. There was an equal number of men and women. The focus group discussion was conducted by the group and observed by the authors, who did not contribute to the discussion in any way. ${ }^{42}$

\section{Ex ante expectations of amalgamation for Guyra}

Analysis of the focus group discussion revealed six themes, each of which is now discussed under a separate heading.

\section{Integrity of merger process}

The discussion among focus group members was founded on an implicit premise that the entire Fit for the Future process had been both unnecessary and undemocratic; it appeared that the decision to merge with the GSC and ADC was done 'to' them, not 'for' them or 'with' them. Their democratic right to choose to remain separate from Armidale had been neglected and ignored, in common with their solution to raise rates by 30 per cent in order to avoid the disruption of a merger. The decision to compulsorily consolidate was felt to be a paternalistic decision imposed by the NSW Government intent on diminishing local government in NSW.

Focus group participants felt the integrity of the merger process - as conducted by the ILGRP and endorsed by KPMG's econometric modelling - was considered erroneous and not based on concrete, objective empirical evidence, particularly the emphasis in official documentation produced by the ILGRP on scale economies. Focus group participants understood that economies of scale resultant from mergers had not been demonstrated in other Australian states or in local government systems abroad and did not flow automatically from simply a larger population size.

Considerable discussion centred on compulsory council consolidations that had occurred previously in the New England region, such as the merger of Armidale and Dumaresq and the creation of the Tamworth Regional council. Focus group participants all believed that the larger councils had neither saved money nor become more efficient than their smaller predecessors. Indeed, it was repeatedly noted that even IPART had not declared all of these previously merged councils as 'fit for the future'. In the light of these discrepancies, the decision to merge - against the wishes of the community - was thus held to be

\footnotetext{
${ }^{41}$ National Institute of Economic and Industry Research (NIERC), Government Areas: Similarities and Differences (2013) 124, <http://www.localgovernmentreview.nsw.gov.au/documents/lgr/NSW\%20Local\%20Government\%20Areas_\%20 Similarities\%20and\%20Differences\%20-\%20March\%202013.pdf >.

${ }^{42}$ All research conducted through the University of New England (UNE) falls under the ethics guidelines of UNE, which are administered by the UNE Ethics Office. Research conducted for this PhD, which encompassed not only GSC, discussed in this article, but also other New England local councils affected by forced amalgamation, is no exception.
} 
illegitimate. The focus group was unanimous that the unique needs of the GSC as a rural community were not being met or acknowledged by the NSW Government because of its 'one size fits all' approach to NSW council reform.

\section{Armidale and Guyra are culturally incompatible}

While participants were at pains to establish the fact that Armidale and Guyra communities were not neighbours 'at war', they acknowledged there was little social or economic interdependence that bound the two together. As a much smaller community with different interests because of its more agriculturally focused, permanent and widely dispersed population, Guyra had problems which were different in both kind and degree from Armidale. This view was aligned with the strongly felt belief that the forced amalgamation would necessarily result in a loss of 'local voice' and 'local choice' for residents of GSC.

The divergence of interests between the two communities meant that the municipal merger did not feel like a grouping of two social, political or economic equivalents. The spatial distance was also a hindrance to closer relations: many people in Guyra did not have access to private transport and public transport was neither reliable nor frequent.

The reputation of the former $A D C$ for controversial and conflict-ridden governance was not viewed warmly. It was agreed among focus group participants that this unsatisfactory state of affairs was unlikely to change post-amalgamation.

\subsection{Rural is 'different'}

The benefits of a rural council in a rural community was discussed at great length by focus group participants. It was felt that a rurally based council understood what a rural community required and could produce locally-tailored solutions accordingly.

The group believed that the GSC was established in 1906 at a time when the reach of the NSW Government did not extend to the rural, regional or remote areas of NSW. Over time, the GSC had provided many fundamentals considered essential for a civil, rural society. It had thus evolved to become responsive to the local community. This tradition had been continued by the GSC to the present era.

The thorny question of unsealed rural roads, which required constant attention, was considered at length by the focus group. For rural people, roads are a vital resource since they are used for both commercial purposes and to ameliorate the social isolation of life in the bush. The GSC had provided a budget for volunteers to assist with road maintenance; however, it was feared that because of the increased layer of council administration and bureaucratisation, roads may not remain as important in the post-amalgamation Armidale Regional Council (ARC).

Participants were also at pains to stress that factors which affect people in the bush are not the same as people in urban areas. For example, adverse weather conditions could destroy a person's entire annual income on a farm or ravage unsealed rural roads thus placing people in difficulties. The group were in broad agreement on the question of how different local government is in rural communities; the forced merger was thus not merely about governance and the loss of a locally-based rural local government which advocated for the best interests of its community, but also a social institution which softened the harshness of life in the bush.

\section{Employment, business and economic environment}

The GSC was the second largest employer in the GSC area and provided a number of different employment opportunities, creating a varied range of skills and social capital. Its close relationship with local businesses and the local labour market were beneficial to the community. During and after the merger process, staff members who had been retained by the newly merged ARC had not been relocated to Armidale. However, most participants feared future positions with the council may not be as easily obtained by Guyra locals. Furthermore, focus group participants held that local businesses which had long and established links with the GSC would now lose business due to the ARC and its competitive tendering process. This would hurt not only Guyra residents but also the overall economy of the new ARC. The elusive pursuit of economies of scale would force the ARC to become more parsimonious in its procurement practices. 
Given the loss of local employees frequenting local business, the resultant multiplier effects would be felt throughout the community; one participant thought that the NSW Government did not understand rural economies since the 'magic pudding' effect did not occur when local government was taken away.

The group questioned whether the newly consolidated ARC would be able to both retain staff and save money, especially because of the labour-intensive role of rural staff. Will it be as proactive in the creation and regulation of the environment necessary for the growth and innovation of business in the former GSC area?

The focus group feared the gradual decline of local business would, in turn, result in the loss of NSW Government and Commonwealth services. In addition, it was felt that essential services, such as health care, banks and local shopping, were endangered, especially as they had been in many other small towns as a result of forced amalgamation.

\section{Social and community consequences}

The consequences for the social and community wellbeing of Guyra was easily the most sensitive point touched upon during the focus group discussion about the amalgamation between the ADC and the GSC. The connectivity felt between Guyra residents to other members of the community had already been blighted, with incipient divisions created by council reforms and the marked movement of council employees from Guyra. A 'sense of place' that many in the focus group had once enjoyed was now at risk from competition for scare council resources.

An example of this loss was noted by a participant as emergency service volunteers. It was claimed that volunteer numbers were already in decline due in part to new council bureaucratisation that had created a fall in emergency-readiness and safety in the area.

Participants foresaw further change and predicted that Guyra would become a harder, less kind place in which to live, where local loyalties no longer mattered. Life in the bush was hard enough - remarked one member of the focus group - due to market forces, weather and isolation, but it would be rendered much more unpalatable if the sense of community, connectivity and kindness between neighbours and friends were to disappear due to the 'balance sheet' approach of NSW Government's local government reform policy.

Focus group members were in agreement in doubting that a new regional community could emerge from the amalgamation process. They understood community building as an organic and slow process, not one created by fiat by distant policy makers.

\section{Local democracy, political representation and the purpose of local government}

The role of local government in the bush was debated by the focus group. For the focus group local government was the closest 'grass roots' democratic institution that was both a local advocate and an economic engine of the community, unlike higher tiers of government that did not have same kind of presence or reach into rural Australia. They considered that - because of the NSW Government's emphasis on achieving economies of scale - local government would become merely a provider of local services. However, according to focus group members, local government in the bush should, instead, reflect accurately the democratic values of the community it served. Participants emphasised that - in their view economic efficiency was not the same as effective local government.

A loss of political transparency and accountability was viewed as an inevitable result of forced amalgamation with a larger council by the focus group. It was felt that increased bureaucracy in the larger council would result in less political choice and reduced power of elected representatives. The focus group believed that the role of councillors, now heavily reduced in number, meant that the human scale of local government was lost. A chasm would inexorably develop between the governed and the government. This in turn would alienate people from participation and involvement in local issues that really mattered to them.

The partisan nature of the newly merged council, with potential councillor's standing as a member of a political party, was not welcome as focus group participant believed party-political influence was not helpful in local government, especially as this would mean some councillor's had a broader, predetermined agenda that would not be compatible with local questions. In turn, this had determined that members of the focus group had lost their faith in Australian political institutions and the democratic process. The 
information flows about the merger process were not clear, logical or straightforward. The NSW Government had not treated the residents with civility in this regard. One participant complained that appeals to stop the merger had been made to two politicians associated with the town, but these had been completely ignored. This buttressed the group's conviction that the political voice and wellbeing of rural Australians was not important in the political calculus of the NSW Government.

\section{Concluding remarks}

The present paper has sought to address a gap in the empirical literature on structural reform and forced amalgamation in Australian local government by exploring the views of local residents in a small rural community in the Northern Tablelands of NSW undergoing a protracted and controversial involuntary merger. We assembled a small focus group comprised of citizens of Guyra - the main centre - in the former GSC which had been compulsorily consolidated with its much larger neighbour, the ADC based in Armidale.

The views expressed by members of the focus group were not only strongly held, but also surprisingly uniform: expectations of the future consequences of the forced merger for the Guyra community were overwhelmingly negative and it was almost universally anticipated that the Guyra community's economic and social wellbeing would be diminished. In addition, almost everyone placed much greater weight on the role played by local government in fostering community cohesion and stimulating local development than the efficiency objectives pursued by the NSW Government.

The responses from the Guyra focus group, regarding their expectations and future consequences of a forced municipal merger for their community, align with much of the extant academic literature. Focus group participants did not believe that forced council consolidation would make local government more cost effective or more efficient and this has been shown in much of the empirical literature regarding council consolidation ${ }^{43}$. Focus group participants also believed that the pursuit of economies of scale, which empirical evidence has shown is often illusive, ${ }^{44}$ has ignored the human dimension of local government, most particularly the requirements of a small, rural community. ${ }^{45}$

These findings could inform public policymakers in future episodes of structural reform through municipal mergers. In particular the finding that local government assumes much greater significance in small rural communities where it is often viewed as 'government of last resort' by local residents. In addition to the dual role of local government in terms of democratic representation and efficient local administration in metropolitan settings and large regional centres, in small rural communities it takes on further responsivities revolving around community development and community cohesion.

While this paper at least initiates empirical research into the attitudes of rural people in small shires undergoing forced amalgamation, it has several limitations, especially the comparatively small size of the focus group. Future research in the area should examine more than a single case study of compulsory consolidation and employ a larger sample size with structured interviews or questionnaires, resources permitting.

\section{References}

Abelson, Peter, and Roselyne Joyeux, 'New Development: Smoke and Mirrors - Fallacies in the New South Wales Government's Views on Local Government Financial Capacity’ (2015) 35 (4) Public Money and Management 315. https://doi.org/10.1080/09540962.2015.1047278

Allan, Percy, 'Why Smaller Councils Make Sense' (2003) 62 (3) Australian Journal of Public Administration 74. https://doi.org/10.1046/j.1467-8500.2003.00339.x

Australian Bureau of Statistics (ABS), Local Government Profile Guyra (2011)

Bell, Brian, Brian Dollery and Joseph Drew, 'Learning from Experience in NSW?' (2016) 35 (12) Economic Papers 1

\footnotetext{
${ }^{43}$ See Brian Bell, Brian Dollery and Joseph Drew, 'Learning from Experience in NSW?' (2016) 35 (12) Economic Papers 1.

${ }^{44}$ Glenn Fahey, Joseph Drew and Brian Dollery, 'Merger Myths: A Functional Analysis of Scale Economies in New South Wales Local Government' (2016) 16(4) Public Finance and Management 362.

${ }^{45}$ Andrea Wallace and Brian Dollery, 'Merging Big and Small: A Cautionary tale from Barraba' (2018) 24(1) Australasian Journal of Regional Studies 62.
} 
Boston, Jonathon, John Martin, June Pallot and Pat Walsh, Public Management: The New Zealand Model (Oxford University Press, 1996)

Department of Infrastructure and Development (DIRD), State of Regional Australia 2015 (2015)

Dollery, Brian, and Joseph Drew, 'Hired Guns: Local Government Mergers in New South Wales and the KPMG Modelling Report' (2017) 27 (82) Australian Accounting Review 263. https://doi.org/10.1111/auar.12163

Dollery, Brian, Blight Grant and Michael Kortt, Councils in Cooperation: Shared Services and Australian Local Government (Federation Press, 2012)

Dollery, Brian, Joe Wallis and Alexandr Akimov, 'One Size Does Not Fit All: The Special Case of Remote Small Local Councils in Outback Queensland (2010) 36 (1) Local Government Studies https: / / doi.org/10.1080/03003930903435716

Drew, Joseph, and Bligh Grant, 'Multiple Agents, Blame Games and Public Policy-Making: The Case of Local Government Reform in New South Wales' (2017) 52 (1) Australian Journal of Political Science 37. https: // doi.org/10.1080/10361146.2016.1238872

Drew, Joseph, and Brian Dollery, 'Estimating the Impact of the Proposed Greater Sydney Metropolitan Amalgamations on Municipal Financial Sustainability' (2014) 34 (4) Public Money and Management 281

Drew, Joseph, and Brian Dollery, 'Summary Execution: The Impact of Alternative Summarisation Strategies on Local Government' (2016) 40 (4)Public Administration Quarterly 814

Drew, Joseph, and Brian Dollery, Brian, 'Less Haste, More Speed: The Fit for the Future Reform Program in New South Wales Local Government' (2015) 75 (1) Australian Journal of Public Administration 7. https:// doi.org/10.1111/1467-8500.12158

Fahey, Glenn, Joseph Drew and Brian Dollery, 'Merger Myths: A Functional Analysis of Scale Economies in New South Wales Local Government’ (2016) 16(4) Public Finance and Management 362

Faulk, Dagney, Pamela Schaal and Charles D Taylor, 'How Does Local Government Amalgamation Affect Spending? Evidence from Louisville, Kentucky’ (2013) 13(2) Public Finance and Management

Guyra Shire Council, Rural Council Proposal (Guyra Shire Council, 2015)

ILGRP, Future Directions for NSW Local Government: Twenty Essential Steps (2013) and ILGRP, Revitalising Local Government (2013)

Independent Local Government Review Panel (ILGRP), Better Stronger Local Government: The Case for Change (2012) 6

KPMG, Local Government Reforms: Merger Impact and Analysis (2015)

KPMG, Outline of Financial Modelling Assumptions for Local Government Merger Proposals (KPMG, 2016)

National Institute of Economic and Industry Research (NIERC), Government Areas: Similarities and Differences (2013) 124, <http://www.localgovernmentreview.nsw.gov.au/documents/lgr/NSW\%20Local\% 20Government\%20Areas_\%20Similarities\%20and\%20Differences\%20-\%20March\%202013.pdf>

New South Wales Government, Local Government Reform: Merger Impacts and Analysis (2015).

NSW Parliamentary Research Service, The New England North-West Region: An Economic Profile (New South Wales Government, 2014) 4

NSW Treasury Corporation (TCorp), Financial Sustainability of the New South Wales Local Government Sector (2013)

Office of Local Government, A Roadmap for Smarter, Stronger Councils (Office of Local Government, 2014)

Page, Don, Joseph, ‘New South Wales Local Government Reform 2011 to 2014' in Brian Dollery and Ian Tiley (eds) Perspectives on Australian Local Government Reform (Federation Press, 2015) 172

Regional Development Australia, Northern Inland (RDA), The Economic Impacts of Local Government Amalgamations (Issue Report no 9, 2015)

Sancton, Andrew, Merger Mania (McGill-Queens University Press, 2000)

Steiner, Reto, 'The Causes and Effects of Intermunicipal Cooperation and Municipal Mergers in Switzerland’ (2003) 5(4) Public Management Review. https://doi.org/10.1080/1471903032000178581 
Tate Consulting Pty Ltd, Assessing Processes and Outcomes of the 2004 Local Government Boundary Changes in NSW (McLaren Vale, South Australia, 2013)

TCorp, ‘Guyra Shire Council: Financial Assessment and Benchmarking Report' (NSW Treasury Corporation, 2013)

TCorp, Financial Sustainability of the New South Wales Local Government Sector (NSW Treasury

Corporation, 2013) 14

Vince, Anne, 'Amalgamations' in Dollery, Brian and Worthington, Neil (eds) Australian Local Government: Reform and Renewal (Macmillan, 1997) 151

Wallace, Andrea, and Brian Dollery, 'Merging Big and Small: A Cautionary tale from Barraba' (2018) 24(1) Australasian Journal of Regional Studies 62 
Appendix A: Development and procedural timeline, NSW Fit for the Future policy package

\begin{tabular}{|c|c|c|c|}
\hline Date & Artefact/Event & Details & NSW Government \\
\hline July 2011 & $\begin{array}{l}\text { Our Communities, } \\
\text { Councils, Future } \\
\text { Discussion Paper }\end{array}$ & $\begin{array}{l}\text { Written by Elton Consulting on behalf of the NSW Government, the case for change } \\
\text { in NSW local government was outlined as a precursor to "Destination 2036" } \\
\text { Workshop. }\end{array}$ & $\begin{array}{l}\text { - } \quad \text { National/Liberal Coalition } \\
\text { - } \quad \text { Barry O'Farrell - Premier } \\
\text { - } \quad \text { Von Page-Minister of Local Government } \\
\quad \text { Forced Amalgamation".' }\end{array}$ \\
\hline August 2011 & Destination 2036 & $\begin{array}{l}\text { A workshop held in Dubbo NSW where the case for change was introduced to } \\
\text { representatives from } 152 \text { NSW councils. }\end{array}$ & \\
\hline June 2012 & $\begin{array}{l}\text { Destination 2036: Action } \\
\text { Plan }\end{array}$ & $\begin{array}{l}\text { Outlining the key role local government plays in the wider NSW economy, a case for } \\
\text { auctioning different structural models for local government was made. }\end{array}$ & \\
\hline March 2012 & ILGRP appointed & $\begin{array}{l}\text { Consisting of Professor Graham Sansom and two former council CEO's Jude Munro } \\
\text { and Glenn Inglis, ILGRP was tasked with reviewing options for NSW local government. }\end{array}$ & \\
\hline August 2012 & $\begin{array}{l}\text { Strengthening Your } \\
\text { Community }\end{array}$ & $\begin{array}{l}\text { ILGRP's initial document, where the panel promised that local government options } \\
\text { would not be a 'one size fits all' approach to reform. }\end{array}$ & \\
\hline $\begin{array}{l}\text { November } \\
2012\end{array}$ & $\begin{array}{l}\text { Better, Stronger Council: } \\
\text { The Case for Sustainable } \\
\text { Change }\end{array}$ & $\begin{array}{l}\text { ILGRP's first major report that outlined challenges the panel believed councils in } \\
\text { NSW would face over the next } 25 \text { years and how local government could strengthen } \\
\text { itself and improve efficacy. }\end{array}$ & \\
\hline $\begin{array}{l}\text { January } \\
2013\end{array}$ & $\begin{array}{l}\text { Assessing processes and } \\
\text { outcomes of the } 2004 \\
\text { Local Government } \\
\text { boundary changes in } \\
\text { NSW. }\end{array}$ & $\begin{array}{l}\text { Jeff Tate Consulting, commissioned by ILGRP, presented research conducted at five } \\
\text { NSW councils that had undergone boundary changes in } 2004 \text {. }\end{array}$ & \\
\hline April 2013 & $\begin{array}{l}\text { Financial Sustainability } \\
\text { of the NSW Local } \\
\text { Government Sector }\end{array}$ & $\begin{array}{l}\text { New South Wales Treasury Corporation (TCorp) presented its analysis of the financial } \\
\text { sustainability and outlook for each of NSW's } 152 \text { councils. }\end{array}$ & \\
\hline April 2013 & $\begin{array}{l}\text { Future Directions for } \\
\text { NSW Local Government- } \\
\text { Twenty Essential Steps }\end{array}$ & $\begin{array}{l}\text { ILGRP's second substantive report whereby the panel recommended the merger of a } \\
\text { number of NSW councils. }\end{array}$ & \\
\hline $\begin{array}{l}\text { October } \\
2013\end{array}$ & $\begin{array}{l}\text { Revitalising Local } \\
\text { Government }\end{array}$ & $\begin{array}{l}\text { ILGRP's final report. Merger recommendations were softened in favour of a } \\
\text { strengthened Boundaries Commission which would be able to make binding } \\
\text { prescriptive changes. }\end{array}$ & \\
\hline $\begin{array}{l}\text { January } \\
2014\end{array}$ & Fit for the Future & Public release of policy package by NSW Government. & \\
\hline $\begin{array}{l}\text { September } \\
2014\end{array}$ & $\begin{array}{l}\text { Implementation of Fit for } \\
\text { the Future }\end{array}$ & $\begin{array}{l}\text { NSW Government embarks upon the implementation of the policy reforms, with } \\
\text { financial incentives offered to facilitate voluntary council mergers. }\end{array}$ & $\begin{array}{l}\text { Barry O'Farrell resigns, Mike Baird ascends to Premier. } \\
\text { Don Page is replaced with Paul Toole as Minister of Local } \\
\text { Government. }\end{array}$ \\
\hline $\begin{array}{l}30 \text { June } \\
2015\end{array}$ & $\begin{array}{l}\text { IPART start evaluation } \\
\text { process. }\end{array}$ & $\begin{array}{l}\text { Individual councils are obliged to lodge its submission report to IPART in order to } \\
\text { undergo the evaluation process. }\end{array}$ & \\
\hline
\end{tabular}




\begin{tabular}{|c|c|c|c|}
\hline Date & Artefact/Event & Details & NSW Government \\
\hline $\begin{array}{l}\text { October } \\
2015\end{array}$ & $\begin{array}{l}\text { Fit for the future: } \\
\text { Review of business case } \\
\text { estimates of merger net } \\
\text { benefits for Sydney } \\
\text { metropolitan councils }\end{array}$ & $\begin{array}{l}\text { Ernst and Young (EY) prepare Sydney merger report. The appointment of EY had not } \\
\text { been publicly announced. }\end{array}$ & \\
\hline $\begin{array}{l}\text { October } \\
2015\end{array}$ & $\begin{array}{l}\text { Assessment of Council Fit } \\
\text { for the Future proposals }\end{array}$ & $\begin{array}{l}\text { IPART's evaluation released, a major decider of which councils will undergo } \\
\text { amalgamations: } 71 \% \text { of Sydney councils and } 56 \% \text { of regional councils were found } \\
\text { 'unfit'. }\end{array}$ & \\
\hline $\begin{array}{l}\text { December } \\
2015\end{array}$ & $\begin{array}{l}\text { Local Government } \\
\text { Reform: Merger Impacts } \\
\text { and analysis }\end{array}$ & $\begin{array}{l}\text { Commissioned by the NSW Government with circulation limited to Cabinet, KPMG } \\
\text { undertook financially modelling to show potential savings from proposed mergers, } \\
\text { thus justified policy impetus. }\end{array}$ & \\
\hline $\begin{array}{l}18 \\
\text { December } \\
2015\end{array}$ & $\begin{array}{l}\text { Merger of several NSW } \\
\text { councils announced }\end{array}$ & & \\
\hline $\begin{array}{l}\text { January } \\
2016\end{array}$ & $\begin{array}{l}\text { Outline of Financial } \\
\text { Modelling assumptions } \\
\text { for local government } \\
\text { merger proposals }\end{array}$ & $\begin{array}{l}\text { KPMG's methodology workbook to show how they had arrived at the financial } \\
\text { forecasts and from where their information was researched. This report was publicly } \\
\text { released. }\end{array}$ & \\
\hline 12 May 2016 & $\begin{array}{l}\text { Forced Government } \\
\text { Amalgamations } \\
\text { announced. }\end{array}$ & Twenty new councils were created after the merger and dissolution of 49 . & \\
\hline 27 July 2017 & $\begin{array}{l}\text { NSW Government } \\
\text { announced it would not } \\
\text { force through remaining } \\
\text { council mergers as the } \\
\text { legal proceedings were } \\
\text { too costly. }\end{array}$ & $\begin{array}{l}\text { - } \quad \text { Burwood, City of Canada Bay and Strathfield Municipal Councils } \\
\text { - Hunsby Shire and Ku-Ring-gai councils } \\
\text { - } \quad \text { Mosman Munill, Lane Cove and City of Ryde councils } \\
\text { - Randwick City, Waverth Sydney and Willoughby City Councils } \\
\text { Due to legal proceedings lodged against the NSW Government by Woollahra and Ku- } \\
\text { Ring-Gai councils, these Sydney Councils listed did not undergo forced council } \\
\text { mergers. }\end{array}$ & $\begin{array}{l}\text { Mike Baird resigns as Premier } 23 \text { January 2017, Gladys } \\
\text { Berejiklian appointed Premier. } \\
\text { Gabrielle Upton becomes Minister of Local Government, } \\
30 \text { January } 2017 .\end{array}$ \\
\hline
\end{tabular}

